\title{
Maternal Men-Perverts and Deviants? Making Sense of Gay Men as Foster Carers and Adopters
}

\author{
Stephen Hicks
}

\begin{abstract}
This article examines discourses of gender and sexuality that feature in the social work assessment of gay men who apply to foster or adopt in the United Kingdom (UK). Using data from interviews with social workers and managers, the author argues that three versions of the category gay were dominant. In the first of these, gay men were imagined to be maternal and/or feminine. In the second, they were seen as a source of perversion and sexual risk, and in the third, they were assumed to present problematic models of gender. The author critiques these ideas, and argues instead for social welfare practices that reconsider and expand our notions of gender, sexuality, parenting, and kinship. [Article copies available for a fee from The Haworth Document Delivery Service: 1800-HAWORTH. E-mail address: <docdelivery@ haworthpress.com> Website: $<$ http://www.HaworthPress.com> ( 2006 by The Haworth Press, Inc. All rights reserved.]
\end{abstract}

KEYWORDS. Gay men, homosexuality, foster care, adoption, parenting, social work assessment

In October 2004, a United Kingdom (UK) national newspaper, The Daily Express, ran a front-page headline story, "Scandal Of The Gay

Stephen Hicks, PhD, DipSW, is affiliated with the School of Community, Health Sciences \& Social Care, University of Salford, Salford, UK (E-mail: s.hicks@ salford.ac.uk).

Journal of GLBT Family Studies, Vol. 2(1) 2006

Available online at http://www.haworthpress.com/web/GLBTF

(C) 2006 by The Haworth Press, Inc. All rights reserved. doi:10.1300/J461v02n01_05 
Dads: How Could Couple Be Allowed To Adopt Three Little Children?" (Baron, 2004). The article described a gay couple, Mark and Chris, who were the foster carers of three siblings-four-year-old Anna, five-year-old Vicky, and eight-year-old Ben. In the UK at that time, only married couples were able to adopt children jointly, and so Mark had adopted all three as a single person in the eyes of the law-a practice that was then common amongst lesbian and gay adoptive couples (Hicks \& McDermott, 1999).

The Daily Express article, however, argued that the couple had "exploited a legal loophole," implying that the adoption was illegal. Some commentators in the article suggested that this made a mockery of the law and that children were not being fully protected (Baron, 2004). Despite Mark and Chris's argument that they were not crusaders for gay adoption, the article also implied that their children might become gay and that their calling both men Daddy was a problem (Baron, 2004). Although the couple made the point that they had been together for 21 years, that they had fostered the children for some time, that the children were formerly living apart and had difficult backgrounds, that the couple had been fully assessed by the adoption agency, and that they did not believe children can become gay because "you're born gay" (Baron, 2004). Nevertheless, the article suggested that adoption by gay men was inappropriate-a scandal (Baron, 2004).

Why should this be the case? Why does the idea of gay men fostering or adopting children provoke such social anxieties? What is it about gay men that is imagined to be so inappropriate to the care of children? Or, perhaps more precisely, what is it that is invoked by the very idea of gayness in relation to other ideas about parenting, care, intimacy, sexuality, gender and the like? This article tries to answer some of these questions through a detailed consideration of some issues concerning gay men who foster or adopt children. It is, therefore, a contribution to a small but growing body of work in this field.

\section{GAY MEN AND FOSTER CARE}

Most research into parenting by gay men has not tended to consider foster care or adoption although these are sometimes mentioned or form a subsection of sample groups (Barret \& Robinson, 1990; Barrett \& Tasker, 2001, 2002; Bozett, 1981, 1985, 1987a, 1987b, 1989; Dunne, 1999, 2000, 2001; Kaeser \& Gillespie, 1999; Strah \& Margolis, 2003;

Weeks et al., 2001). However, there are now a small number of studies, 
including my own, which do consider the specifics of gay foster care and adoption (Hicks, 1993, 1998, 2000, 2003, 2005a, 2005b, in press a; Hicks \& McDermott, 1999; Mallon, 2000, 2004; Ricketts, 1991; Ricketts \& Achtenberg, 1990; Riggs, 2004a, 2004b; Skeates \& Jabri, 1988).

There are many reasons for this lack of research but one is that, compared with lesbians, gay men are far less likely to apply to foster or adopt children. They are less likely than lesbians to consider parenting in the first place but of those that do apply to foster or adopt, shorterterm care of young people is more common than permanent placements including adoption (Brooks \& Goldberg, 2001; Hicks, 1998). There are historical reasons for this with gay men reporting that they did not imagine foster care or adoption as possibilities in the past. Such stories of impossibility, however, are being replaced by narratives of opportunity and choice in the field of gay parenting (Weeks et al., 2001), and this is also the case with foster care and adoption specifically (Hicks \& McDermott, 1999). Nevertheless, gay men remain in the minority of foster carers or adopters when compared with either lesbians or heterosexuals.

However, this article examines some other reasons for the small numbers of gay men who foster or adopt. Instead of asking why gay men are less likely to become parents, which of course is an important question, I discuss what I see as a series of barriers that prevent this. First, gay parenting is devalued by discourses that assert the legitimacy of natural heterosexual care as evidenced by the Daily Express article (Baron, 2004). In addition, child welfare agencies, responsible for placing children with foster and adoptive carers, also demonstrate problems with the very idea of gay men as parents. One social worker, for example, told me that his agency's adoption panel would not consider gay men because it had concerns about the forcing of a gay lifestyle onto a child (Hicks, 1998).

Finally, even where gay men are accepted and assessed by adoption and foster care agencies, then the practices of social work operate various ideas about sexuality, gender and parenting which both draw upon and produce particular versions of the category gay. In this article, I discuss the ways in which gay is made sense of through social work in terms of ideas about maternal men as perverts and gender deviants/deviance. That is, I ask, when social workers go about assessing gay men as potential foster carers or adopters, what ideas about sexual identities or, rather, categories are brought into play? I argue that social work asserts particular versions of gay and that, as Leo Bersani (1995) has 
noted, this attempted stabilizing of identity is inherently a disciplinary project of social work. My data are derived from my own research (Hicks, 1993, 1998; Hicks \& McDermott, 1999) as well as press reports (Baron, 2004), the UK Houses of Parliament debates on gay adoption in 2002 , and the work of other authors referred to within the text.

\section{GAY MEN AS FOSTER CARERS AND ADOPTERS}

The number of gay men who have fostered or adopted children in the UK is not known. However, evidence from my research as well as my involvement in national support groups for lesbian and gay carers demonstrates that there are a small number of gay adopters and slightly more foster carers. There are many more lesbian than gay men foster carers and adopters. Of the contributors to Lesbian and Gay Fostering and Adoption (Hicks \& McDermott, 1999), for example, 18 are lesbians and 9 gay men. Of those gay men, just 2 (a couple) have adopted, and all the others are foster carers. In addition, most of the gay men are caring for young people rather than younger children.

Although I have observed this pattern in previous research (Hicks, 1993, 1998), it is not possible to say that this is anything other than a general trend and may be one that is changing as more gay men begin to consider foster care and adoption as possibilities (Mallon, 2004; Strah $\&$ Margolis, 2003). Further, my concern is not that gay men should foster or adopt as I fully support those who do not wish to consider these options. Rather, I wish to ask why, for those gay men who do want to become foster carers or adopters, these possibilities are limited by a set of what I will refer to as dominant heteronormative discourses. I will explain what I mean by this through an example.

The work of Frederick W. Bozett on gay fathers in the United States was pioneering as his was one of the earliest interventions and series of investigations (Bozett, 1981, 1985, 1987a, 1987b, 1989). However, Bozett argues for a dual identities thesis in which the gay father must work towards the successful integration of two opposing ideas, i.e., gay and father:

By actively functioning both as a gay as well as a father, in time he can eliminate cognitive dissonance and place himself in the cognitive category of gay father. By these means, then, the gay father achieves identity congruence and self-acceptance. (Bozett, 1981: 559) 
I do not find this model useful because it locates the meanings given to categories such as gay and father within a psychological process and series of states. That is, the subject is taken to be the source of meaning. Instead, an approach concerned with heteronormativity and discourse would argue that gay fathers are open to a range of interpretations of their identities which they do not own or control since those identities (in all situations but especially in state-sanctioned foster care and adoption) are assessed. They are subjected to scrutiny and interpretation which has the effect of producing and maintaining ideas about what a gay father can or should be. In addition, those interpretations are not freely chosen but are derived from a series of quite limited discourses about sexuality and parenting that circulate through societal texts, talk, and practices.

Heteronormativity is an idea derived from queer theory, and it refers to a situation in which heterosexuality is taken to be "the elemental form of human association, as the very model of inter-gender relations, as the indivisible basis of all community, and as the means of reproduction without which society wouldn't exist" (Warner, 1993, p. xxi). Queer theory has argued that heteronormativity is about the delegitimization of homosexuality and that it works to define the homosexual as abnormal and the heterosexual as unremarkable (Halperin, 1995). It is my view that state foster care and adoption practices currently operate heteronormative ideas, and in this article, I will demonstrate how applications by gay men throw these ideas into question.

In addition, heteronormativity is a practice of knowledge-a position from which understandings of categories such as lesbian or gay are asserted. Thus, even though gay men who apply to foster or adopt make their own statements about their lives and about their identities, they are stereotyped through the practices of social work. A foster care or adoption panel, responsible for the decision about whether to approve an applicant, knows the gay man only through a textually mediated form (Smith, 1990), i.e., the social worker's assessment report. Further, that panel requires a series of ideas about sexuality and parenting to be addressed, and I aim to show how these represent the operations of heteronormativity in action.

Discourse theory is similarly concerned with the ways in which practices and texts attempt to build up and maintain authoritative knowledge about types such as the gay man. Discourses are groups of statements sanctioned by some form of authority that often display a similar pattern or set of rules. They constitute the objects of which they speak but only in certain ways so as to exclude other ways of thinking (Cheek, 2000; 
Mills, 1997). Thus, we might think of the practices of social work assessment as attempts to order ways of thinking about sexuality and parenting but also as ways to confer authority upon some versions and to exclude others. Crucially, a concern with discourse means that we should not treat ideas like sexuality, gender, the gay man, and so on as already predetermined. Instead, we must examine how these ideas are constituted within the social world, and how they are subject to disputes which, although they clearly allow for resistance and objection, nevertheless seek to uphold dominant accounts.

For my purposes, then, queer and discourse theories imply that statements about gay men as fathers or as foster carers and adopters are not helpful when they impute an essential state or individual psychology to that category. Instead, I ask how the very idea of the gay foster/adoptive carer is constructed and maintained in particular forms through the processes of social work discourse. It is for these reasons that I focus on the versions of gay men notions that are arrived at through the process of social work assessment.

\section{REASSESSING GAY MEN AS POTENTIAL FOSTER CARERS AND ADOPTERS}

Social work is now far more likely to come across gay foster care or adoption applicants who are out or open about their sexuality from the start of the assessment process. Many gay applicants were circumspect about or did not discuss their sexuality in the past (Skeates \& Jabri, 1988) but this has changed so that most gay men who apply to fostering or adoption agencies now expect their sexuality to be taken seriously and treated fairly (Ricketts \& Achtenberg, 1990). However, many gay applicants have reported that they felt that questions about their sexuality came to dominate the entire assessment (Barret \& Robinson, 1990; Hicks, 1998), or, at the other extreme, that it was ignored altogether (Hicks, 1998; Ricketts, 1991).

My own research has examined the process of social work assessment of gay applicants (Hicks, 1993, 1998), and I would suggest that this results in a series of particular ideas about gay male ideations, all of which involve the construction of a positive or negative but essential difference (Hicks, 2005a). That is, what I have referred to as heteronormative discourses result in and display an anxiety to maintain the gay man as a distinct category set apart from that of the heterosexual to uphold what Jennifer Terry (1995) has termed "us-and-them" distinc- 
tions. In addition, these ideations of the gay man both draw upon and assert notions about gender, sexuality, parenting, and risk to children that result in concepts that I have termed maternal men, perverts, and gender deviants/deviance.

\section{Maternal Men?}

Discourses about the family and kinship tend to claim heterosexual relations and biogenetic adult-child bonds as the basis of "proper" natural parenting (Hicks, 2005b, in press a, b; Mallon, 2004). Within the UK, for example, social commentators and sociologists working for conservative think-tanks (such as Melanie Phillips and Patricia Morgan) as well as some Christian organizations argue that lesbian and gay parenting is morally wrong and, indeed, damaging to children. They claim the heterosexual, married couple as the gold standard for child care (Christian Institute, 2002; Morgan, 2002; Phillips, 1999). There are similar examples in the United States (see those discussed in Buss \& Herman, 2003; Stacey, 1996; Struening, 2002). These ideas also exist in everyday versions including some of the interventions into the UK uses of Parliament debates on gay adoption in 2002 as well as ideas about child development, families, and gender role models.

Gay men are imagined to disrupt this set of ideas because they challenge the supposed link between heterosexual relations and parenting. In addition, gay men who apply to foster or adopt, like all foster carers and adopters, inevitably question the view that biogenetic adult-child links are proper forms of kinship. Finally, however, gay men also present a challenge to the often implicit view that the care of children is appropriately assigned as women's work. That is, as men, gay men are not usually seen as the natural carers of children, and, as gay, they are not seen as natural parents.

Within foster care and adoption agencies, many workers are not used to the idea of men caring for children. For example, some social workers told me that when assessing heterosexual couples to foster or adopt, they were really imagining that the woman would be doing most of the child care (Hicks, 1998). I also found that social workers made statements such as, "There is more of a tradition of women bringing up children," or "We're prejudiced against male carers," when describing their reactions to men, not necessarily gay men, as applicants. This discourse tends to construct men as predatory and as the potential abusers of children but also suggests that men are not nurturers by their nature (Hicks, 1998). 
The social workers also spoke of working with a number of women carers who were not in relationships with men; some of whom were lesbians. Most of the social workers that I spoke to told me that because they and their panels were used to women caring for children, lesbians were not assumed to pose such a threat as gay men. This does not mean that lesbian applicants were readily accepted (Hicks, 2000) but I did find that agencies and their panels were far more wary of gay men as potential foster carers and adopters.

It is my view that, for those social workers, panels, and agencies that did approve gay men, the idea that they might pose some kind of threat to the discourse of natural parenting and, indeed, to children as such had to be addressed in some way. Here, then, the idea that men are dangerous to children was reversed so that in some cases gay men were reimagined as maternal or, indeed, feminine. Statements included: "He took a very female role"; or "He offers traditionally 'Mum'-things, and traditionally female strengths" (Hicks, 1998). One social worker described a gay male couple that she had assessed as follows:

One of them actually took on a much more traditional maternal role, and the other paternal, and people are looking for those in panel. (Hicks, 1998, p. 291)

In these examples, then, gay men are figured as feminine, as taking on a female role, or performing traditional socially assigned female tasks. That is, the very activities associated with the daily care of children are imagined to be female because they are usually performed by women. However, the final quotation above also demonstrates that a gay couple may also be interpreted as taking up male and female roles where one of them is doing most of the child care. That is, a gay couple might be represented as heterosexual-like for the purposes of an assessment. In both examples, gay men are assumed to occupy a gender role but predominantly an inverted one.

Other research on gay fathers has suggested that they may be more nurturing than heterosexual men and that they may represent a blend of mother/father roles or androgynous gender roles (Bigner \& Bozett, 1990; Bozett, 1989). However, as with the ideas about female roles suggested by the social workers, it is important to remember that these are ways of making sense of gay men as the carers of children; they are not essential qualities. That is, when the tasks associated with the care of children are performed by gay men, then they may be interpreted as feminine because it is women who are most likely to look after children. 
However, I also think that the representation of gay men as feminine acts as a way to address and defuse the threat that a gay sexuality is assumed by some to pose for children. Indeed, I would also suggest that there may be a de-gaying process in action here too. What I mean by this is that heteronormative values often imagine a gay sexuality to be threatening because it is too political. For example, some social workers found any challenge to heteronormativity by gay applicants inappropriate:

One of them was much more active politically around his sexuality and, in the preparation group, he really hammered it home, and a bit too much I think because every issue that came up he wanted to address sexuality which was a bit over the top in the end. This need to promote and promote and promote raised a big question for us about how resolved was he with his stuff? (Hicks, 1998, pp. 305306)

As D.A. Miller (1992) has noted, "Society continues to prefer the sotto voce stammering of a homosexuality from which nothing in fact is more tolerated, more desired, than it be ... insignificant" (p. 24). Of course, lesbians and gay men make sense of sexuality in a number of ways (Whisman, 1996) but social work prefers the account that argues homosexuality is an innate and private matter-a variation on heterosexuality-rather than any kind of politically or socially derived idea.

Maternal men, then, are not threatening in two ways: (1) they are feminine and perform the caring tasks associated with women; and (2) they are not too political about their sexuality. In addition, they may even be represented as akin to a heterosexual couple where they perform male and female roles. Social work tends to construct acceptable gay carers as maternal and nonthreatening. This may be partly understandable given that those social workers and agencies that do want to work positively with gay men nevertheless function within a heteronormative field that reinforces many homophobic ideas. So, for example, I found that those social workers who were opposed to homophobia-some of whom were lesbian or gay themselves-told me that they still had to address the homophobic concerns of others, e.g., managers, birth families, and panels. However, this also has the effect of reinforcing some very fixed ideas about gender and sexuality especially the idea that gay men caring for children must be maternal, and it may even hark back to models of gender inversion (Terry, 1995). 


\section{Perverts?}

Whilst the idea of gay men as maternal represents them as unthreatening, there are other discourses associated with the category gay which portray them as dangerous. One of the most prominent of these is a discourse of suspicion-the idea that gay men will adversely affect, influence, and corrupt children. As Barrett and Tasker (2002) have noted:

A huge variety of fears and prejudices prevails, for example, that gay men will encourage peculiar dress habits, effeminate behaviour, and all kinds of perverse sexual practices in their offspring or that they will challenge all the standard tenets of society and leave children uncontrolled, unsure about what is right and wrong, confused about their own sexual orientation and vulnerable to 'predation' from peers as well as from adults. (pp. 3-4)

I found examples of this in my interviews with social workers. One foster care team manager, for example, told me:

We haven't (interestingly enough) had gay men offering to look after very small children, and I would say we would probably have quite a bit of time convincing a panel as to why, and that is to do with prejudice about why men want to care for small children [team manager, inner city foster care team]. (Hicks, 1998, p. 288)

The team manager's identification of prejudice is concerned with a suspicion about the motives of gay men applying to care for children, and this suggests and is linked to the idea of gay men as child abusers (Barret \& Robinson, 1990; Riggs, 2004b). As with the Daily Express article (Baron, 2004), it is also in relation to younger children that these ideas often emerge. That is, younger children are seen as more impressionable and, therefore, corruptible than young people who are assumed to have already formed a gender and sexual role. These notions rely on the problematic view that gender/sexuality are fixed entities derived from socialization by parents, a point I return to in the next section. Indeed, some of the social workers were concerned that gay men might influence the sexual development of children so that they also would become gay (Hicks, 1998).

I argue that there are two versions of the discourse of suspicion in action here: (1) that which is linked to gay men as males; and (2) that which is linked to them as gay. As we have already noted, the category 
men or males as carers raised concerns for the social workers who were used to working with children who had been abused by, in the main, heterosexual men known to those children. One team manager said, "Gay men are going to have a much more difficult time because, well, there are more men abusers and men are seen as more predatory and not the natural carers of children" (Hicks, 1998, p. 293).

However, the category gay raised some particular concerns about the potential sexual exploitation or corruption of children since some social workers saw gay men as sexually abnormal:

Colleagues will say, 'Oh, they're so promiscuous.' We had a discussion about sexuality one day and I just could not believe what I was hearing because I was under the misconception that I was working with enlightened beings! I was absolutely shocked because I could not believe the homophobic utterances. One colleague said, 'You have to accept that it is a fact that homosexual men are so promiscuous,' and another said, 'I can't bear the thought of what men do together sexually.' So the stereotypical thing is promiscuity and instability as well as disgusting sexual practices and contamination of innocent minds, all that kind of thing. (Hicks, 1998, p. 294)

Here an adoption worker (in this case a black, heterosexual woman) clearly articulates what she sees as a set of stereotypical and homophobic ideas about gay men held by social workers in her team. Ideas about gay men often draw upon this notion that they are hyper-sexual and engage in exotic sexual practices. In some versions, such discourses display an almost obsessive concern with supposedly gay sexual acts but also perform the task of making clear and essential distinctions between anything gay-as-abnormal and heterosexual-as-normal sex (Cameron, 1993).

Although there are other less extreme versions of this discourse, nevertheless they suggest that gay men are sexually promiscuous, sexually abusive, and therefore unsuitable for child care. In my view, this is linked to a problem within discourses about appropriate child care, and it is this: to express the idea that someone might be a gay parent and also a person with sexual desires is a problem.

Social work reinforces these ideas through a set of heteronormative practices within fostering and adoption work. For example, social work assessment rightly takes the question of the potential abuse of children by foster care and adoption applicants seriously, but in some cases will 
not allow for the notion of a carer who is also a person with adult sexual desires. Gay men seem to raise this question for some social workers because gay is an identity which is linked with sexual desire and imagined to be hyper-sexual in ways that the heterosexual is not. For example, Wayne, an adoption worker, told me:

Alright, I am married to a woman, and I go home and see my two daughters and, if my wife is sitting there and I want to kiss her or put my arms around her and they (the children) are there that wouldn't be a problem for us. On the other hand, if we are sitting down with arms around each other and one of my daughters walks into the room that's not a problem for us. The problem I have with the gay or lesbian situation is that to have placed a child in there-it's the socialization of that sort of situation. How is it explained to the child? Basically, I think I have to accept anyway that, in my view, it is not the norm. (Hicks, 1998, data files)

Here, we notice that Wayne sees heterosexual affection as normal and unlikely to affect or upset children, whereas gay or lesbian affection is assumed to present a problem, something abnormal that cannot be explained to a child, and that will not properly socialize that child into a correct gender and sexual identity.

A number of other ideas about gay men, e.g., that they are promiscuous, that they do not have long-term relationships, that they are sexually dangerous, also circulate within social work practice evidenced by the fact that social workers are often required to address these concerns by managers and panels. Joy Holloway's (2002) paper on foster care and adoption, for example, suggests that gay men do not have stable relationships, and that they do pose a risk of sexual abuse. These claims can be easily disputed (Hicks, 2003) but it is also important to ask other questions, e.g., Why should foster care and adoption be seen as the preserve of the traditional stable couple? Can't people in other types of relationships be considered? Is relationship stability something that is readily fixed and predictable? And why are gay men associated with sexual abuse in ways that heterosexuals are not?

In response to the latter question, I have discussed ways in which the discourse of suspicion within social work constructs gay men as perverts. They are imagined as dangerous, as hyper-sexual, or as promiscuous; all of which are methods used to equate the category gay with an essential and problematic difference. However, these notions or differ- 
ences are maintained not only in relation to sexuality but also rely upon notions about gender, and it is to these that I now turn.

\section{Gender Deviants and Deviance}

Gay men are also imagined to be a problem for children because they challenge the idea that proper child development requires a male and female role model within the home. Judith Butler (2004) has referred to this as "a certain anthropological belief . . . that culture itself requires that a man and a woman produce a child, and that the child have this dual point of reference for its own initiation into the symbolic order, where the symbolic order consists of a set of rules that order and support our sense of reality and cultural intelligibility" (p. 118). These ideas figured, for example, in the UK House of Lords debate on gay adoption:

Damaged children need both male and female role models-a mother and a father. Homosexual adoption would deliberately place some of the most damaged children in a home without either a father or a mother. Is that in the interests of the child? ... How would they feel if their friends knew that they had either two dads or two mums? It is likely that they would be mocked and made to feel even more different. (Baroness O'Cathain, House of Lords debate, 16th October 2002, column 884)

Baroness O'Cathain's (2002) speech brings together a number of important ideas used to oppose all forms of lesbian and gay parenting. The first of these is the suggestion of double burden for children placed with gay or lesbian carers. This idea argues that children who already have to deal with the stigma or difficulties of being fostered or adopted should not be subject to the extra burden that having gay or lesbian parents is supposed to provoke. Alongside this argument, O'Cathain (2002) also suggests that children with gay or lesbian carers will be stigmatized by their peers because of their alleged difference. She claims to speak on behalf of children rather than herself by arguing that gay parenting is not in the child's interests. This is a device commonly used by the opponents of lesbian and gay adoption as it allows their own moral opposition to gay parenting to be hidden behind a claim to represent the voice of the child. Finally, O'Cathain (2002) also refers to what she sees as the need for all children to have a male and female role model within the home. 
This argument-that gay parenting is problematic because it denies children required gender role models-is one of the most ubiquitous within fostering and adoption work as well as wider debates on gay parenting. In relation to the assessment of gay men, I found this idea manifested itself in a number of different ways. First, gay men were imagined to inhabit an all-gay-male world in which they had no contact with women as stated by an adoption worker:

In their social groups, are they only socializing with men because they are also men? Are they socializing with men who are the same, like a club? What women do they know? To ask things like that would be useful. (Hicks, 1998, p. 284)

Despite the fact that gay men usually have quite complex social networks (Cant, 2004), here they are assumed to know only other gay men to whom they are similar. Indeed, I found that social workers often assumed that gay men would know only other gay men, and they further insisted that they must be integrated with the community, meaning heterosexuals. Social workers required gay men to have relationships with the wider community, and that they not only seek friendships with people who share their own sexual orientation but who also had a family life (Hicks, 1998). Apart from the anxiety that gay men do not have contact with heterosexuals, these ideas also pose further problems: (1) they define family as an essentially heterosexual institution; (2) they rest on a very limited view of community and family that does not acknowledge that gay and lesbian people often form close emotional and supportive bonds with a network of friends (Weston, 1991); and (3) they deny the importance, in my view, of close contacts with other gay and lesbian parents and their children.

Here, in direct contrast to the maternal men discourse, it is assumed that gay men cannot provide female contacts. Gay men seem to be ultramale and absent of female influence. This idea was also used by the social workers to discuss whether gay men were the appropriate carers for boys or not. Once again, there is a contradiction here: as opposed to the notion that gay men might pose a sexual threat to boys under the discourse of suspicion, here I found that many social workers assumed that gay men should care for boys rather than girls. In fact, many said that gay men caring for girls would be inappropriate because they would not be able to handle sensitive intimate care issues (e.g., bathing, dressing, talking about puberty, and menstrual periods). This presented a problem for some of the social workers: they were used to asking female carers 
to provide intimate care to boys and girls and often counseled heterosexual male carers not to do this. When they applied this argument to gay men, however, suspicions about intimate care of boys were raised or they assumed that caring for girls was inappropriate.

The second way in which the idea of gay male gender roles was interpreted was one in which gay men are not seen as proper men. Some research has claimed that gay fathers present less traditional male role and more androgynous gender role models to their children (Bigner \& Jacobsen, 1989; Dunne, 1999, 2000). In some cases, this has been reinterpreted as indicating gender dysfunction in gay parents and their children (Morgan, 2002). So, in my view, arguments made in the Houses of Parliament debates, in the media (Baron, 2004), and within social work about the need for male and female role models suggest not only that gay men cannot provide a female influence but concomitantly that they are also a bad male role model because gay men are seen as feminine or insubstantially masculine from a traditional viewpoint.

It is possible to answer these concerns with evidence that gay male carers are nurturing, have good relationships with their children and with other adults, do not expect their children to maintain rigid gender roles, and have family/friendship networks that are complex and include women. It is also possible to cite evidence that the children of gay fathers form good peer relationships, are not confused about gender roles and identities, and are no more likely to have been abused or to identify as gay or lesbian (Bailey et al., 1995; Barret \& Robinson, 1990; Barrett \& Tasker, 2001, 2002; Bigner \& Bozett, 1990; Bigner \& Jacobsen, 1989; Bozett, 1987a, 1987b; Cant, 2004; Dunne, 1999, 2000; Mallon, 2004; Strah \& Margolis, 2003). However, this does not address the more difficult issue which is how the discourses of gender and sexuality attempt to maintain the view that gay men hold an essentially different gender role or sexual identity that can be passed on to or inherited by their children. That is, dominant discourses of gender and sexuality assert that these are things acquired by children through parental influence or the process termed socialization mentioned earlier by Wayne, the adoption worker ((Hicks, 1998, data files).

Socialization theory argues that children learn a gender from parents when young. One of the reasons that gay men as foster carers or adopters pose a problem for socialization theory, therefore, is because any questioning of traditional gender models and also the idea of a lesbian or gay sexuality must be written off as mal-socialization or deviance (Stanley \& Wise, 1993). Instead, my own approach, largely influenced by feminist and ethnomethodological work on gender (Butler, 2004; 
Demo \& Allen, 1996; Fenstermaker et al., 2002; Golombok \& Fivush, 1994; Jackson \& Scott, 2002; Kessler \& McKenna, 1978; Smith, 1990; Stanley \& Wise, 1993; Thorne, 1993; West \& Zimmerman, 1987), would argue that gender is not a role or thing inherited by children from their parents but is instead something that is performed and imputed by people in everyday life.

Thus, whether or not someone is seen as a man or a woman or as masculine or feminine is an idea relative within particular contexts. In addition, how children make sense of gender or understand their own gender is not as a fixed role established through their parenting experiences but rather a complex and contradictory set of rules for behavior which they actively interpret and at various times reject or accept. Gender is, then, practiced differently within different situations by the same person and may be interpreted differently by different audiences. Certainly, it is a far more complex idea than boys are like this-girls are like that as Barrie Thorne (1993) notes.

Dominant discourses of gender, however, aim to establish and maintain rigid distinctions between types of men (e.g., gay men are

straight men are ___ and also between men and women as we have seen through the many examples discussed in this paper. So it is also important to ask why the correct socialization of children into limited and constraining gender roles is a good thing. However, I have also argued that gender is not a fixed role but is rather "the activity of managing situated conduct in light of normative conceptions of attitudes and activities appropriate for one's sex category" (West \& Zimmerman, 1987 , p. 125). We have seen that engaging in activities not normally associated with the category man such as caring for children results in a challenge to those normative conceptions: gay men are imagined as gender deviants, and this deviance is assumed to affect their children.

\section{DEVELOPING SOCIAL WELFARE PRACTICE WITH GAY MEN WHO CARE FOR CHILDREN}

In this article, I have demonstrated that the category gay men is actively made sense of through social work processes involving talk, texts, and other practical activities. Gay men have been imagined as essentially maternal and perverse or gender deviant-all of which are active interpretations and assertions about the category gay. That is, social welfare is implicated in the construction of our ideas about sexuality and, in my view, also maintains heteronormative values about 
parenting, care, and intimacy. As Carol-Anne O'Brien (1999) has noted, "Social work and social welfare . . . are far from being socially neutral or limited to technical interventions; they are deeply implicated in the construction of power relations in sexuality" (p. 151).

I have also argued that applications by gay men to foster or adopt children throw the discourse of heteronormative ideas about parenting into question. That is, a set of otherwise everyday and unquestioned social work values and processes are subject to scrutiny resulting in a series of anxieties about gender and sexuality. Parenting or caring tasks that are associated with men and women (e.g., discipline, provision of income, gender roles, cleaning, cooking, bathing, and so on) are suddenly to be performed solely by gay men-an idea that does not fit with dominant discourses about gender, sexuality and the parenting task.

How, then, might social welfare practice develop in ways that are committed to questioning homophobic as well as traditionally gendered practices? Whilst there are large areas of social welfare that remain heteronormative and ignorant of lesbian and gay concerns (Brodzinsky et al., 2002; Brooks \& Goldberg, 2001; Hicks, 1998, in press a, b; Hicks \& McDermott, 1999; Mallon, 2000, 2004; Ryan, 2000), a further response, sometimes referred to as equality, has been to argue that sexuality is irrelevant. Damien Riggs (2004a), for example, notes that "foster carer training often promotes the idea that sexuality is not an important issue when considering potential foster carers" (p. 11), and, within the UK, this idea has been confirmed by policy documents that argue sexuality should not be a concern within social work assessments (Department of Health, 2001, 2002; Romaine, 2003).

However, such equality measures, whilst having the good intention of opposing discrimination on the basis of sexuality, also tend to discourage any discussion of lesbian and gay concerns within assessments. That is, the statement that sexuality is no determinant of parenting ability (Golombok, 2000) is reinterpreted to mean that a person's sexuality or indeed sexual politics ought not to be discussed at all. Most lesbian and gay applicants, on the other hand, appreciate the opportunity to talk about their sexuality within the context of an application to care for children (Hicks \& McDermott, 1999).

In addition, social welfare practice needs to examine the ways in which its heteronormative ways of working contribute to the achievement of quite fixed and limited ideas about the categories lesbian or gay. Rather than adding in lesbian or gay foster care and adoptive applicants to an otherwise unchanged system of practice, I have argued instead that social welfare needs to develop a critical reflexivity about the 
ways in which it maintains and upholds heteronormative views about parenting, gender and sexuality (Hicks, in press b).

In my view, one of the reasons that social work maintains discriminatory views about gay men is because foster care and adoption work operates a narrow set of ideas about kinship, intimacy, and care. This is highly ironic given that foster care and adoption are practices which themselves should help to question standard views of kinship. However, within this field, conventional views about the family, about gender, and about sexuality predominate, and so gay men come to represent something of a problem. I have also argued that social work continues to discipline the category gay, so that in some cases gay men will be rejected outright by foster care and adoption agencies (Hicks, 1998; Hicks \& McDermott, 1999). Even where gay men are assessed, however, my point has been that particular versions of gay such as unthreatening, apolitical, private, integrated, and so on are favored.

Instead, social work might do a lot more to learn about the novel forms of kinship and care that have been developed by some lesbians and gay men (Hicks, in press a, b; Riggs, 2004a; Weeks et al., 2001; Weston, 1991). Gay men who apply to foster or adopt usually demonstrate a great commitment to the desire to parent as well as creativity about how to form less rigid or conventional families (Hicks \& McDermott, 1999; Mallon, 2004; Strah \& Margolis, 2003). In addition, they have probably had to think in depth about why and how they wish to become parents and will have had to challenge a lot of prejudice about this along the way. These can all be extremely useful lessons for any potential foster or adoptive carer.

Gay men also display a far wider and more challenging set of ideas about gender, sexuality, and parenting than those discussed in this piece. This does not mean that gay men's ideas are always unconventional and innovative. Gay men are as much influenced by dominant discourses about gender and sexuality as anyone else. But social work must also ask not why gay men present a challenge to ideas about gender, sexuality and parenting but rather how those ideas about family life can be expanded.

There are now some published narratives by gay men who have fostered or adopted (Hicks \& McDermott, 1999; Kaeser \& Gillespie, 1999; Mallon, 2004; Strah \& Margolis, 2003), and these might act as a starting point for social work students, practitioners and educators to examine their own reactions to the idea of gay men caring for children. My point is that the field of foster care and adoption needs to do more to examine wider and more creative views of human kinship and intimacy, and it 
also needs to challenge ideas about gender and sexuality. Expanding horizons in this way will help to develop a creative foster care and adoption field that is able to offer children a less rigid model of human relationships and kinship.

\section{REFERENCES}

Bailey, J. M., Bobrow, D., Wolfe, M., \& Mikach, S. (1995). Sexual orientation of adult sons of gay fathers. Developmental Psychology, 31(1), 124-129.

Baron, C. (October 4, 2004). Scandal of the gay dads: How could couple be allowed to adopt three little children? The Daily Express, pp. 1-2.

Barret, R.L., \& Robinson, B.E. (1990). Gay fathers. Lexington, MA: Lexington Books.

Barrett, H., \& Tasker, F. (2001). Growing up with a gay parent: Views of 101 gay fathers on their sons' and daughters' experiences. Educational and Child Psychology, 18(1), 62-77.

Barrett, H., \& Tasker, F. (2002). Gay fathers and their children: What we know and what we need to know. Lesbian \& Gay Psychology Review, 3(1), 3-10.

Bersani, L. (1995). Homos. Cambridge, MA: Harvard University Press.

Bigner, J. J., \& Bozett, F.W. (1990). Parenting by gay fathers. In F. W. Bozett \& M. B. Sussman (Eds.), Homosexuality and family relations (pp. 155-175). New York: Harrington Park Press.

Bigner, J. J., \& Jacobsen, R. B. (1989). Parenting behaviors of homosexual and heterosexual fathers. In F.W. Bozett (Ed.), Homosexuality and the family (pp. 173-186). New York: Harrington Park Press.

Bozett, F. W. (1981). Gay fathers: Evolution of the gay father identity. American Journal of Orthopsychiatry, 51(3), 552-559.

Bozett, F. W. (1985). Gay men as fathers. In S. M. H. Hanson \& F. W. Bozett (Eds.), Dimensions of fatherhood (pp. 327-352). Beverly Hills, CA: Sage.

Bozett, F. W. (1987a). Children of gay fathers. In F. W. Bozett (Ed.), Gay and lesbian parents (pp. 39-57). New York: Praeger.

Bozett, F. W. (1987b). Gay fathers. In F. W. Bozett (Ed.), Gay and lesbian parents (pp. 3-22). New York: Praeger.

Bozett, F. W. (1989). Gay fathers: A review of the literature. In F. W. Bozett (Ed.), Homosexuality and the family (pp. 137-162). New York: Harrington Park Press.

Brodzinsky, D. M., Patterson, C. J., \& Vaziri, M. (2002). Adoption agency perspectives on lesbian and gay prospective parents: A national study. Adoption Quarterly, 5(3), 5-23.

Brooks, D., \& Goldberg, S. (2001). Gay and lesbian adoptive and foster care placements: Can they meet the needs of waiting children? Social Work, 46(2), 147-157.

Brown, H. C. (1991). Competent child-focused practice: Working with lesbian and gay carers. Adoption \& Fostering, 15(2), 11-17.

Buss, D., \& Herman, D. (2003). Globalizing family values: The Christian right in international politics. Minneapolis: University of Minnesota Press.

Butler, J. (2004). Undoing gender. New York: Routledge. 
Cameron, P. (1993). Medical consequences of what homosexuals do. Washington, DC: Family Research Institute. Retrieved from http://www.qrd.org/qrd/religion/anti/ cameron/medical.consequences.of.what.homosexuals.do.txt.

Cant, B. (2004). Facilitating social networks among gay men. Sociological Research Online, 9(4). Retrieved from http://www.socresonline.org.uk/9/4/cant.html.

Cheek, J. (2000). Postmodern and poststructural approaches to nursing research. Thousand Oaks, CA: Sage.

Christian Institute (2002). Adoption law-Sidelining stability \& security. Newcastleupon-Tyne, UK: Christian Institute. Retrieved from http://www.christian.org.uk/ html-publications/adoption_briefing2.htm.

Demo, D. H., \& Allen, K. R. (1996). Diversity within lesbian and gay families: Challenges and implications for family theory and research. Journal of Social and Personal Relationships, 13(3), 415-434.

Department of Health (2001). Adoption: National adoption standards for England. London: The Stationery Office. Retrieved from www.dh.gov.uk/assetRoot/04/01/ 47/01/04014701.pdf .

Department of Health (2002). Fostering services: National minimum standards, fostering services regulations. London: The Stationery Office. Retrieved from www.dh.gov.uk/assetRoot/04/07/35/66/04073566.pdf.

Dunne, G.A. (1999). The different dimensions of gay fatherhood: Report to the Economic \& Social Research Council. London: Gender Institute, London School of Economics.

Dunne, G.A. (2000). The different dimensions of gay fatherhood: Exploding the myths. London, UK: Gender Institute, London School of Economics. Retrieved from http:// www.lse.ac.uk/collections/genderInstitute/pdf/gayfatherhood.pdf.

Dunne, G.A. (2001). The lady vanishes? Reflections on the experiences of married and divorced non-heterosexual fathers. Sociological Research Online, 6(3). Retrieved from http://www.socresonline.org.uk/6/3/dunne.html.

Fenstermaker, S., West, C., \& Zimmerman, D. H. (2002). Gender inequality: New conceptual terrain. In S. Fenstermaker, \& C. West (Eds.), Doing gender, doing difference: Inequality, power, and institutional change (pp. 25-39). New York: Routledge.

Golombok, S. (2000). Parenting: What really counts? London: Routledge.

Golombok, S., \& Fivush, R. (1994). Gender development. Cambridge, UK: Cambridge University Press.

Halperin, D.M. (1995). Saint Foucault: Towards a gay hagiography. New York: Oxford University Press.

Hicks, S. (1993). The experiences of lesbians and gay men in fostering and adoption: A study of the impact of the process of assessment upon prospective carers. Unpublished MA thesis, Economic \& Social Studies, University of Manchester, UK.

Hicks, S. (1998). Familiar fears: The assessment of lesbian and gay fostering and adoption applicants. Unpublished $\mathrm{PhD}$ thesis, Applied Social Science, Lancaster University, UK.

Hicks, S. (2000). "Good lesbian, bad lesbian ...”: Regulating heterosexuality in fostering and adoption assessments. Child \& Family Social Work, 5(2), 157-168. 
Hicks, S. (2003). The Christian right and homophobic discourse: A response to "evidence" that lesbian and gay parenting damages children. Sociological Research Online, 8(4). Retrieved from http://www.socresonline.org.uk/8/4/hicks.html.

Hicks, S. (2005a). Is gay parenting bad for kids? Responding to the "very idea of difference" in research on lesbian and gay parents. Sexualities, 8(2), 153-168. DOI: $10.1177 / 1363460705050852$

Hicks, S. (2005b). Sexuality: Social work theories and practice. In R. Adams, L. Dominelli, \& M. Payne (Eds.), Social work futures: Crossing boundaries, transforming practice (pp. 141-153). Basingstoke, UK: Palgrave.

Hicks, S. (in press a). Queer genealogies: Tales of conformity and rebellion amongst lesbian and gay foster carers and adopters. Qualitative Social Work.

Hicks, S. (in press b). Lesbian and gay foster care and adoption: A brief UK history. Adoption \& Fostering.

Hicks, S., \& McDermott, J. (Eds.) (1999). Lesbian and gay fostering and adoption: Extraordinary yet ordinary. London, UK: Jessica Kingsley Publishers.

Holloway, J. (2002). Homosexual parenting: Does it make a difference? A re-evaluation of the research with adoption and fostering in mind. Newcastle-upon-Tyne, UK: Christian Institute. Retrieved from http://www.christian.org.uk/htmlpublications/homosexualparenting.htm.

Jackson, S., \& Scott, S. (Eds.) (2002). Gender: A sociological reader. London: Routledge.

Kaeser, G. (photographs), \& Gillespie, P. (Ed.) (1999). Love makes a family: Portraits of lesbian, gay, bisexual, and transgender parents and their families. Amherst, MA: University of Massachusetts Press.

Kessler, S. J., \& McKenna, W. (1978). Gender: An ethnomethodological approach. New York: John Wiley \& Sons.

Mallon, G. P. (2000). Gay men and lesbians as adoptive parents. Journal of Gay \& Lesbian Social Services, 11(4), 1-22.

Mallon, G. P. (2004). Gay men choosing parenthood. New York: Columbia University Press.

Miller, D. A. (1992). Bringing out Roland Barthes. Berkeley, CA: University of California Press.

Mills, S. (1997). Discourse. London, UK: Routledge.

Morgan, P. (2002). Children as trophies? Examining the evidence on same-sex parenting. Newcastle-upon-Tyne, UK: Christian Institute.

O'Brien, C. A. (1999). Contested territory: Sexualities and social work. In A.S. Chambon, A. Irving, \& L. Epstein (Eds.), Reading foucault for social work (pp. 131155). New York: Columbia University Press.

Phillips, M. (1999). The sex-change society: Feminised Britain and the neutered male. London, UK: The Social Market Foundation.

Ricketts, W. (1991). Lesbians and gay men as foster parents. Portland, ME: National Child Welfare Resource Center for Management \& Administration, University of Southern Maine.

Ricketts, W., \& Achtenberg, R. (1990). Adoption and foster parenting for lesbians and gay men: Creating new traditions in family. In F. W. Bozett \& M. B. Sussman 
(Eds.), Homosexuality and family relations (pp. 83-118). New York, NY: Harrington Park Press.

Riggs, D. (2004a). Resisting heterosexism in foster carer training: Valuing queer approaches to adult learning and relationality. Canadian Online Journal of Queer Studies in Education, 1(1). Retrieved from http://jqstudies.oise.utoronto.ca/journal/ viewarticle.php?id=3\&layout=html.

Riggs, D.W. (2004b). The psychologisation of foster care: Implications for lesbian and gay parenting. PsyPag Quarterly, 51, 34-43.

Romaine, M. (for British Association for Adoption \& Fostering) (2003). Assessing lesbian and gay foster carers and adopters. London: BAAF.

Ryan, S. D. (2000). Examining social workers' placement recommendations of children with gay and lesbian adoptive parents. Families in Society: The Journal of Contemporary Human Services, 81(5), 517-528.

Skeates, J., \& Jabri, D. (Eds.) (1988). Fostering and adoption by lesbians and gay men. London: London Strategic Policy Unit.

Smith, D. E. (1990). Texts, facts, and femininity: Exploring the relations of ruling. London: Routledge.

Stacey, J. (1996). In the name of the family: Rethinking family values in the postmodern age. Boston: Beacon Press.

Stanley, L., \& Wise, S. (1993). Breaking out again: Feminist ontology and epistemology. London: Routledge.

Strah, D., with Margolis, S. (2003). Gay dads: A celebration offatherhood. New York: Jeremy P. Tarcher/Penguin.

Struening, K. (2002). New family values: Liberty, equality, diversity. Lanham, MD: Rowman \& Littlefield Publishers.

Terry, J. (1995). Anxious slippages between "us" and "them": A brief history of the scientific search for homosexual bodies. In J. Terry, \& J. Urla (Eds.), Deviant bodies: Critical perspectives on difference in science and popular culture (pp. 129169). Bloomington, IN: Indiana University Press.

Thorne, B. (1993). Gender play: Girls and boys in school. Buckingham, UK: Open University Press.

Warner, M. (1993). Introduction. In M. Warner (Ed.), Fear of a queer planet: Queer politics and social theory (pp. vii-xxxi). Minneapolis: University of Minnesota Press.

Weeks, J., Heaphy, B., \& Donovan, C. (2001). Same sex intimacies: Families of choice and other life experiments. London: Routledge.

West, C., \& Zimmerman, D. (1987). Doing gender. Gender \& Society, 1(2), 125-151.

Weston, K. (1991). Families we choose: Lesbians, gays, kinship. New York: Columbia University Press.

Whisman, V. (1996). Queer by choice: Lesbians, gay men, and the politics of identity. New York: Routledge.

RECEIVED: April 15, 2005

ACCEPTED: May 31, 2005 